\title{
CHARACTERIZATION OF THE PARTICLE SIZE FRACTIONS OF BENTONITE CLAY FROM GINOVCI, REPUBLIC OF NORTH MACEDONIA
}

\author{
Boško Boškovski, Slobodan Bogoevski \\ Faculty of Technology and Metallurgy, "Ss Cyril and Methodius" University in Skopje, \\ Rugjer Bošković 16, 1000 Skopje, Republic of North Macedonia \\ bboskovski@tmf.ukim.edu.mk
}

\begin{abstract}
A b s t r a c t: The examined bentonite clay contains montmorillonite as a basic mass. As an admixtures it containes quartz, illite and other minerals. The admixtures are inhomogeneously distributed in various particle size fractions. The subject of this research is concentration and separation of existing admixtures from bentonite clay $(-0.063 \mathrm{~mm})$, a commercial product of Bentomak. Wet sieve analysis and elutriation were applied as separation methods. In order to define the efficiency of the methods, a complex examination for characterization of the fractions was realized. Simultaneous review of the results of XRD, microscopic examinations and chemical analysis indicates that in the finest fraction $(-0.032 \mathrm{~mm})$ the concentration of the admixures is smaller for $80 \%$ than in the other fractions.
\end{abstract}

Key words: bentonite clay, admixtures, particle size fractions, wet sieve analysis, elutriation

\section{INTRODUCTION}

Bentonite clays are widespread in the northeastern region of the Republic of North Macedonia. Clay sediments were formed in Tertiary basins due to volcanic activity. Clay deposits were discovered in the Kratovo-Zletovo volcanic area, precisely in Slaviško Pole (Kriva Palanka region) and in the catchment area of the river of Pčinja (Kumanovo region). Bentonite clay deposits are located in the villages of Rankovce, Ginovci and Ljubanci (Figure $1)$.

The clay deposit in Rankovce is located in the western part of Slaviško Pole. Bentonite clay was formed by the process of alteration of volcanic tuffs, and exist in a Pliocene sediments. The deposit has three layers of bentonite. At the bottom is a layer about $6 \mathrm{~m}$ thick, with a basic tuff mass. Then there is a layer of montmorillonite clay, about $25 \mathrm{~m}$ thick. Above is a layer of bentonite about $11 \mathrm{~m}$ thick, which has several layers of sandy clay. The deposits in Ginovci and Ljubanci are contiguous, and are located east of Rankovce. Two layers of bentonite clay about $1 \mathrm{~m}$ thick are present in a Pliocene sediments (Spasovski et al., 2003; Stojanović, 2005).

Bentomak Mines exploit the clay deposits in Slaviško Pole. The company has a surface exploitation of fine dispersed bentonite, and manufacture several types of bentonite products with high quality: alkali-activated bentonite, casting grade bentonite, drilling mud bentonite, injecting grade bentonite, bentonite grade used for pelletizing processes of the ore concentrates, and as filter (Figure 2).

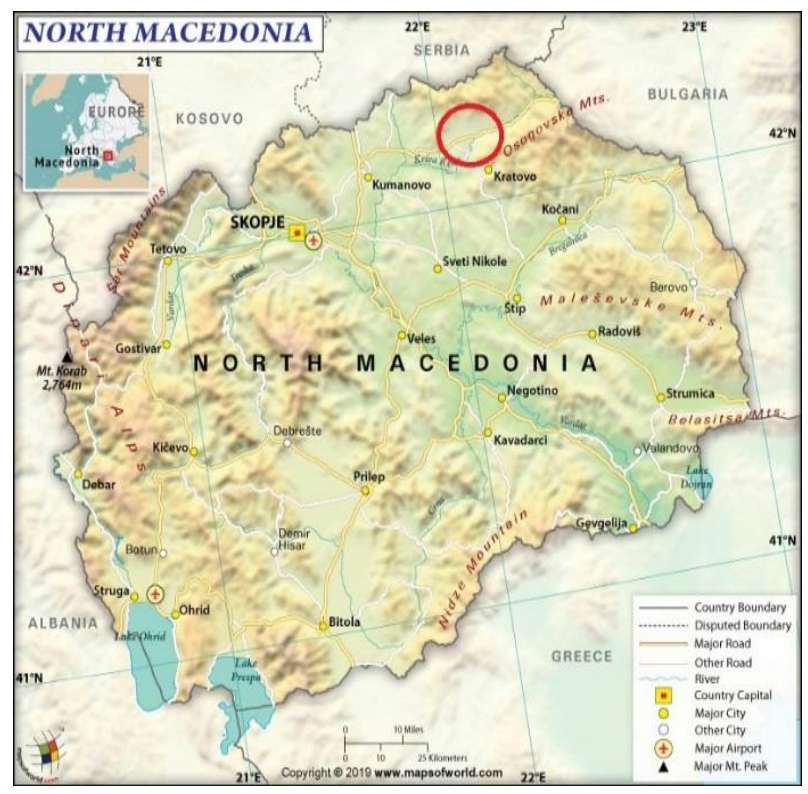

Fig. 1. Geographical location of the deposits 


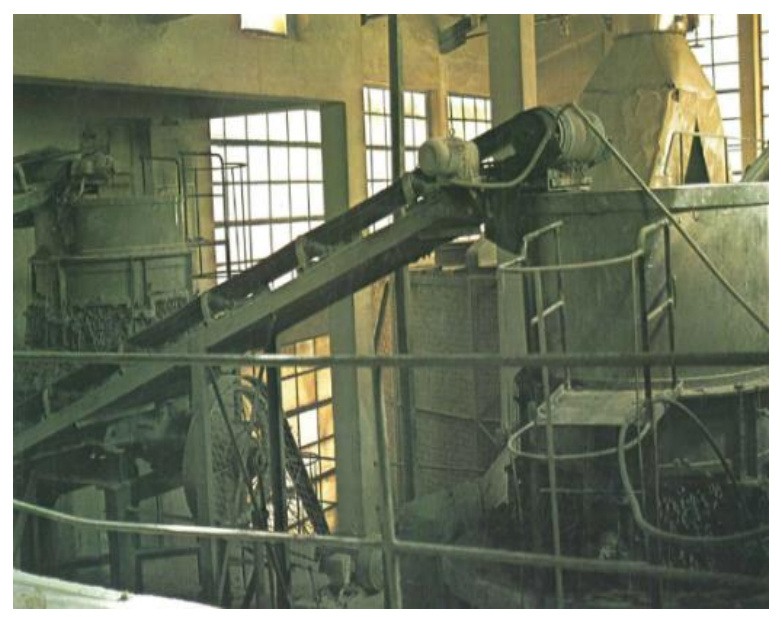

Fig. 2. Bentomak production plant

In order to determine the composition, structure and properties, the bentonite clay mined from these deposits was the subject of many studies and examinations (Atkovska et al., 2016; Boševska 1980; Brezovska; 1996; Brezovska et al., 2004, 2005; Memedi et al., 2017).
Montmorillonite has a dominant mass content in the bentonite clays. Also as admixtures there are quartz, tridymite, opal, calcedon, including hydromicas, particularly in the teregenic form. The weakly expressed boundaries of montmorilonite crystals and higher negative electric charge of there layered crystal lattice provide a large ionic - exchange capacity. The presented mixtures have a negative impact on the properties of the bentonite clay. Therefore, there is a tendency to upgrade the technological process in manufacturing bentonite clay with minor quantities of admixtures. Bentonite clay separated of admixtures has a high profitable implementation (Guera et al., 2013; Khan et al., 2017; Moosavi 2017; Park et al., 2016).

The main goal of this research, is to separate admixtures from bentonite clay.Wet sieve analysis and elutriation were applied as methods for separation of the existing admixtures (Knežević, 2001; Nikolovski, 1995; Zafirovski et al., 1974; Alves et al., 2016; Barakan et al., 2019; Sarbatly et al., 2009; Bogoevski et al., 2016).

\section{MATERIALS AND METHODS}

In this research the bentonite clay $(-0.063$ $\mathrm{mm}$ ), a commercial product of Bentomak, was examined (Figure 3).

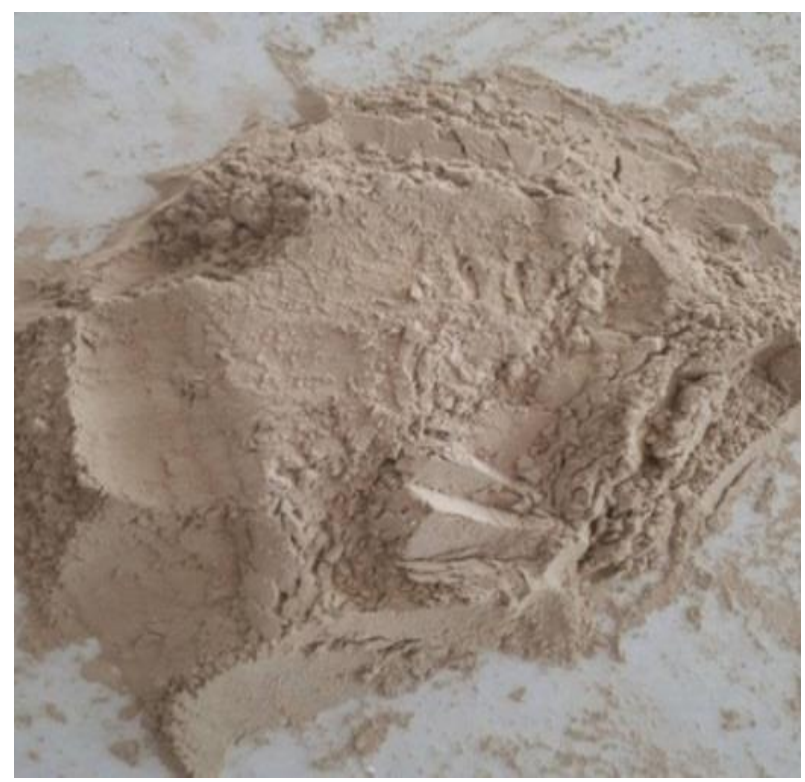

Fig. 3. Bentonite clay $(-0.063 \mathrm{~mm})$, a commercial product of Bentomak

For characterization of the bentonite clay, as well as the separated fractions were applied: che- mical analysis, XRD analysis, DTA/TGA and mineralogical-petrographic examinations.

Chemical composition was defined by silicate chemical analysis (Zafirovski et al., 1974; Bogoevski et al., 2014; Reka et al., 2014; Pavlovski et al., 2011). Existing minerals were determined on a DRON X-ray diffractometer $\left(2 \theta=2-60^{\circ} ; \mathrm{U}_{\mathrm{A}}=38\right.$ $\mathrm{kV} ; \mathrm{I}_{\mathrm{A}}=18 \mathrm{~mA} ; 1 \% \mathrm{~min}$; $\left.\mathrm{CuK} \alpha / \mathrm{Ni}\right)$. DTA/TGA were performed on a Perkin Elmer-7 Diamond instrument, in an air atmosphere with rate of heating $10 \%$ min from ambient to $1000^{\circ} \mathrm{C}$. Mineralogicalpetrographic examinations were realized on Carl Zeiss Jena optical microscope, as well on FEI Quanta 3D FEG electron microscope.

A set of standard sieves with perforation size of $0.063 \mathrm{~mm}, 0.050 \mathrm{~mm}, 0.040 \mathrm{~mm}$ and $0.032 \mathrm{~mm}$ were used for a wet sieve analysis on $50 \mathrm{~g}$ of bentonite clay. Elutriation was performed on a glass tube with diameter of $42 \mathrm{~mm}$, discontinuously on twostage with various flow of water in opposite direction. Elutriation 1 with water flow of $Q_{1}=180$ $\mathrm{cm}^{3} / \mathrm{min}$., and Elutriation 2 with $Q_{2}=120 \mathrm{~cm}^{3} / \mathrm{min}$. A suspension of $10 \mathrm{~g}$ bentonite clay and $300 \mathrm{~cm}^{3}$ of distilled water was prepared for elutriation. In order to prevent aggregation of clay particles, the suspension was heated up to $50^{\circ} \mathrm{C}$ and several drop of $\mathrm{NH}_{4} \mathrm{OH}$ were added. 


\section{RESULTS AND DISCUSSION}

The commercial product of bentonite clay was initially characterized. The average chemical composition is presented in Table 1 .

Some deviations in the chemical and mineralogical composition of the clay are a consequence of natural variations in the deposits. According to XRD presented on Figure 4, the commercial product of bentonite clay contains montmorillonite, quartz, calcium carbonate and sodalite.

DTA/TGA curves are presented on Figure 5. Characteristically for montmorillonite, DTA curve has two endothermic peaks. In correlation, TGA curve has an intensive loss of mass (hygroscopic water) up to $200^{\circ} \mathrm{C}$, and loss of mass (structural water) at temperature range of $600-800^{\circ} \mathrm{C}$.
Table 1

Average chemical composition of the commercial product of bentonite clay (mass \%)

\begin{tabular}{cc}
\hline \hline $\mathrm{SiO}_{2}$ & 54.56 \\
$\mathrm{Al}_{2} \mathrm{O}_{3}$ & 11.74 \\
$\mathrm{Fe}_{2} \mathrm{O}_{3}$ & 5.43 \\
$\mathrm{CaO}$ & 9.15 \\
$\mathrm{MgO}$ & 0.72 \\
$\mathrm{~K}_{2} \mathrm{O}$ & 0.90 \\
$\mathrm{Na}_{2} \mathrm{O}$ & 1.97 \\
$\mathrm{SO}_{3}$ & 0.50 \\
$1 . \mathrm{w}$ & 14.28 \\
$\Sigma$ & 99.25 \\
\hline \hline
\end{tabular}

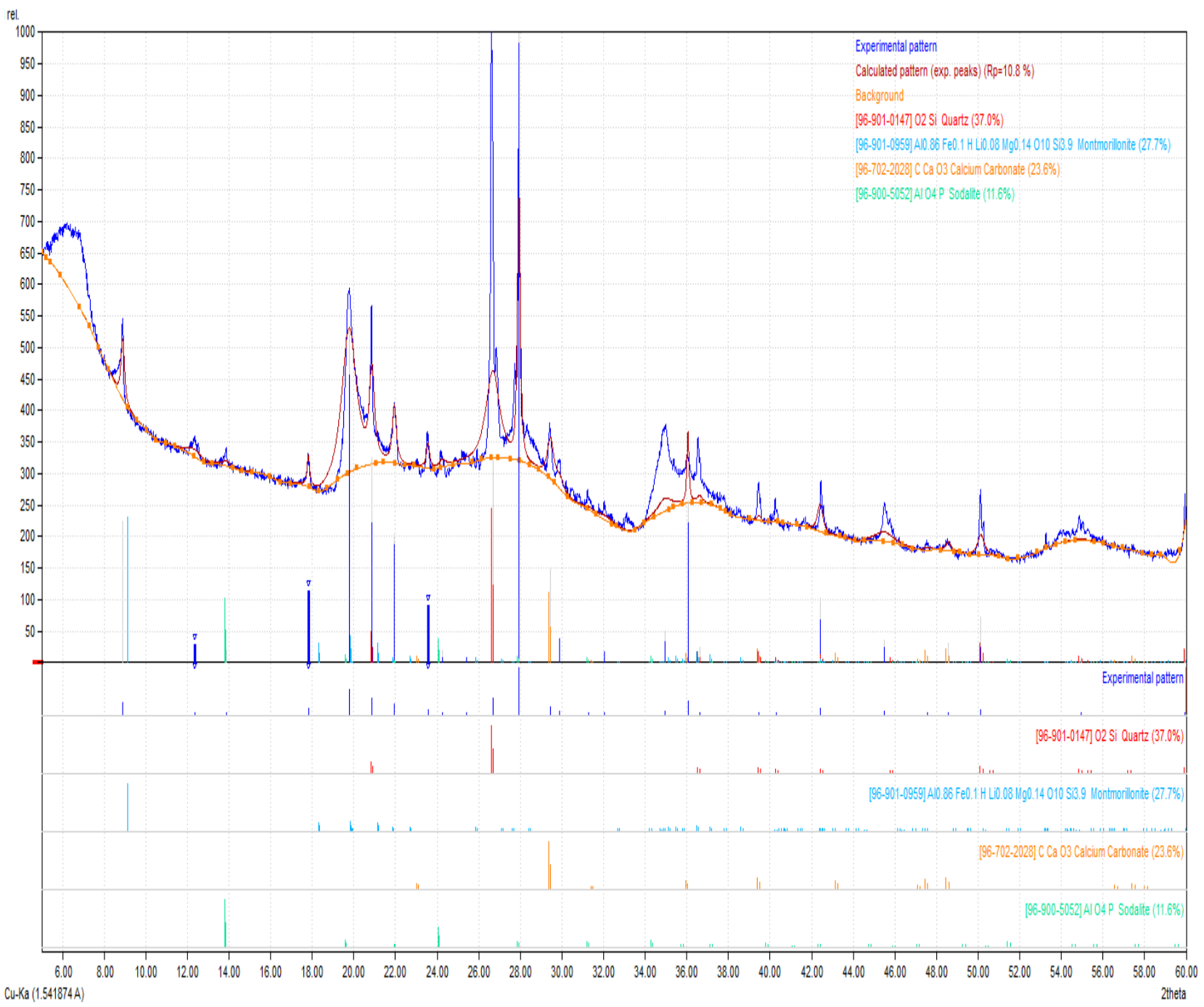

Fig. 4. XRD of the commercial product of bentonite clay 

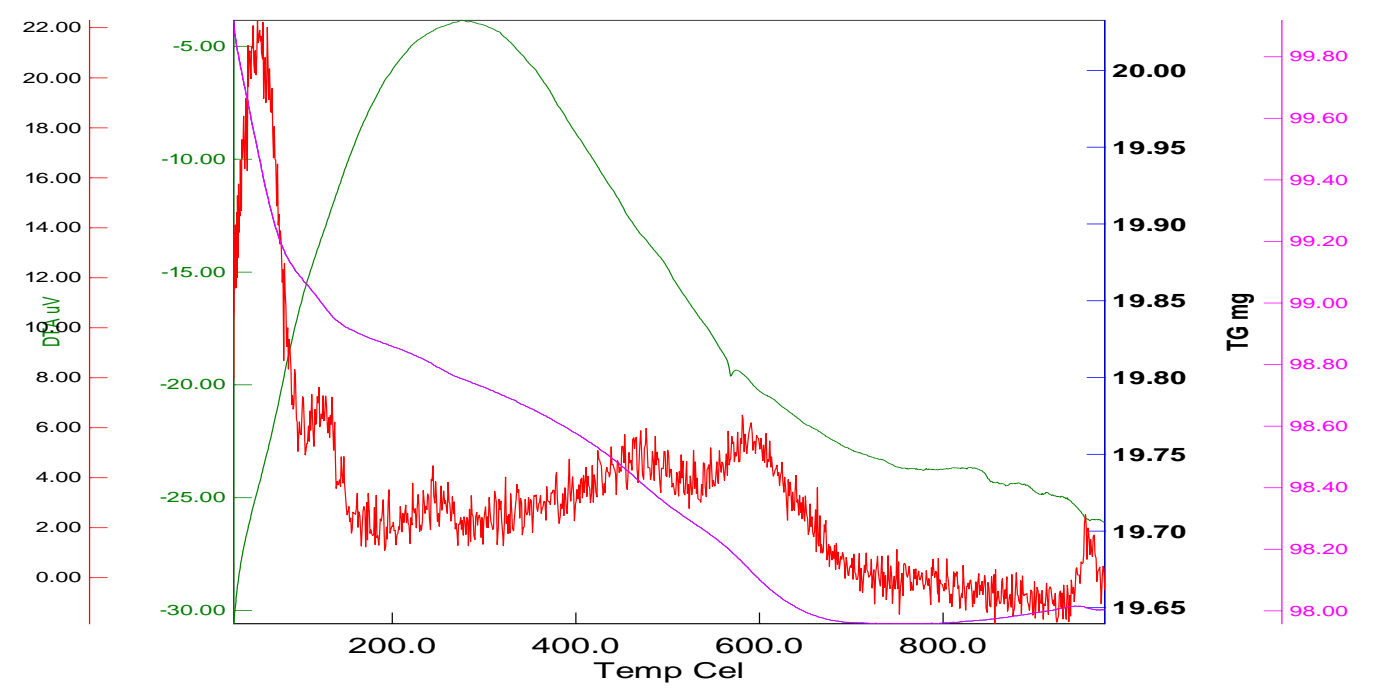

Fig. 5. DTA/TGA of the commercial product of bentonite clay

As a primary method for separation of the existing admixtures from bentonite clay, a wet sieve analysis was applied (Figure 6).

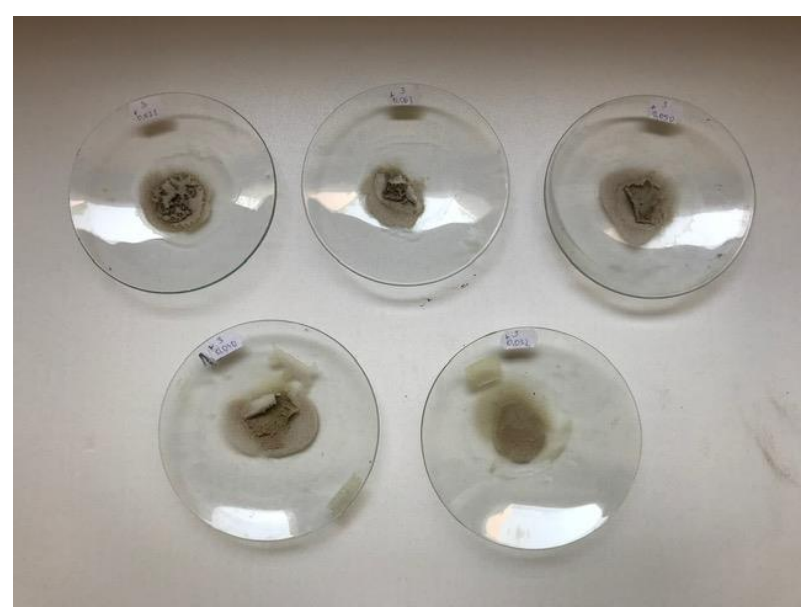

Fig. 6.Various particle size fractions retained on sieves
The mass contents of the particle size fractions, are presented in Table 2 .

Table 2

Wet sieve analysis of bentonite clay

\begin{tabular}{cc}
\hline \hline Fraction $(\mathrm{mm})$ & Mass content $(\%)$ \\
\hline$+0.063 \mathrm{~mm}$ & 4.54 \\
$-0.063+0.050 \mathrm{~mm}$ & 6.44 \\
$-0.050+0.040 \mathrm{~mm}$ & 3.78 \\
$-0.040+0.032 \mathrm{~mm}$ & 5.10 \\
$-0.032 \mathrm{~mm}$ & 80.14 \\
$\Sigma$ & 100.00 \\
\hline \hline
\end{tabular}

Clay absorbs water and expanding, therefore for comparison purposes, asieve analysis using alcohol was realized (Figure 7).

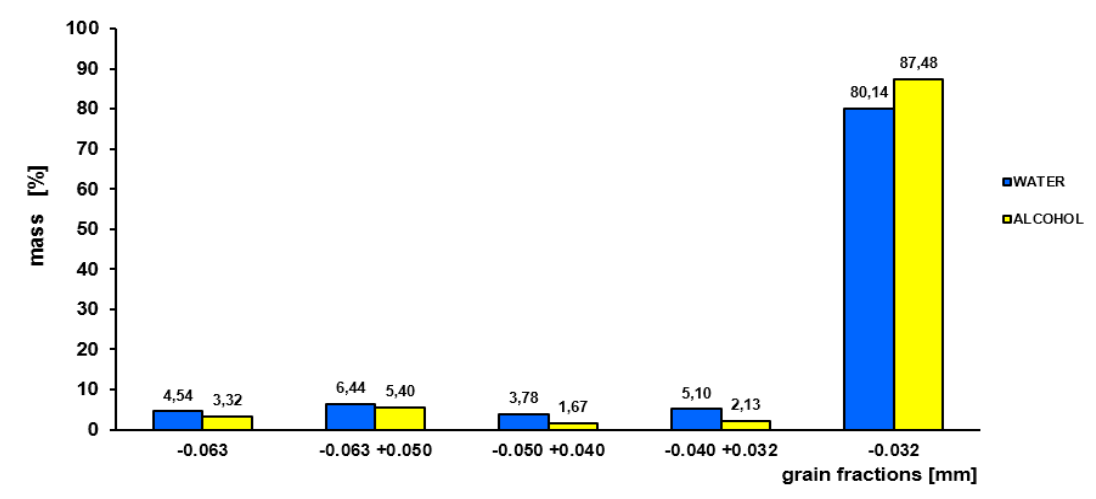

Fig. 7. Comparative histogram of sieve analysis 
According to XRD on Figure 8, in the coarsest fraction $(+0.063 \mathrm{~mm})$ quartz, sodalite and phlogopite were determinated (phlogopite is not determinated in the commercial product of bentonite clay, because is below the detection limit).
The admixtures were also concentrated in the other coarse fractions $(-0.063+0.050 \mathrm{~mm},-0.050$ $+0.040 \mathrm{~mm}$ and $-0.040+0.032 \mathrm{~mm})$. In the finest fraction $(-0.032 \mathrm{~mm})$ from wet sieve analysis the concentration of admixtures is negligible, and contain clay as basic mass (Figure 9).

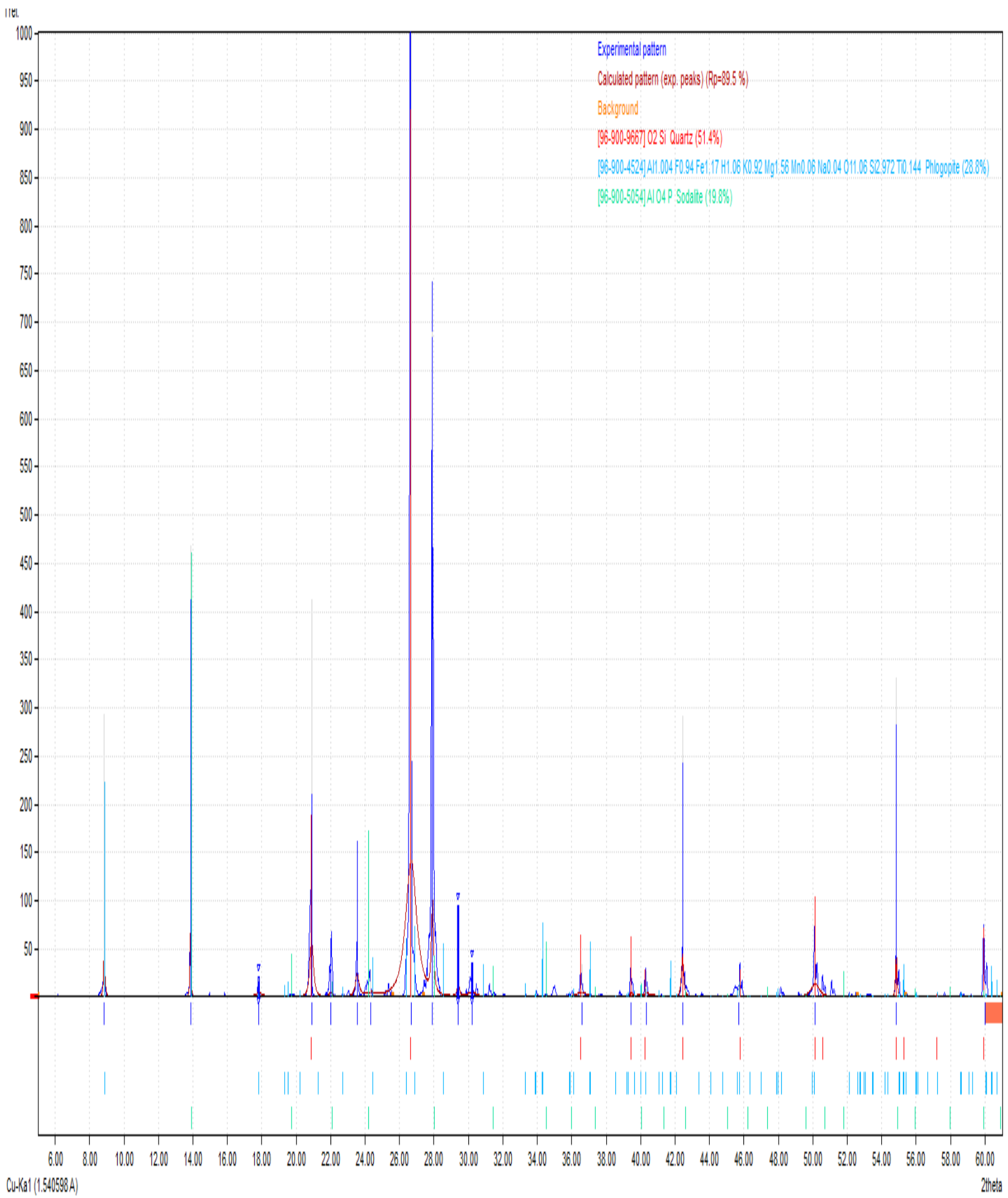

Fig. 8. XRD of the coarsest fraction $(+0.063 \mathrm{~mm})$ from wet sieve analysis 


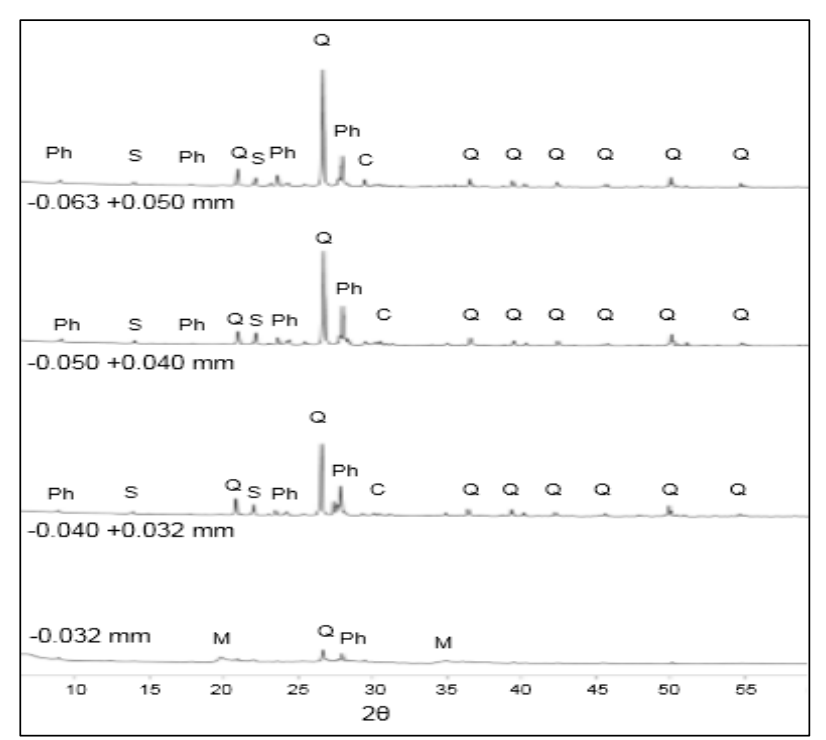

Fig. 9. XRD of various particle size fractions from wet sieve analysis $(\mathrm{Q}$ - quartz, $\mathrm{S}$ - sodalite, $\mathrm{Ph}$ - phlogopite, $\mathrm{C}$ - calcite, $\mathrm{M}$ - montmorillonite)

Microscopic examinations confirm the X-ray analysis. Coarse fractions from wet sieve analysis have dominant content of transparent clear quartz particles (Figures $10-13$ ). Yellow is the particles of phlogopite, turquoise green particles of sodalite and milky white particles of calcite are also present in the coarse fractions. There is minor content of clay aggregates.

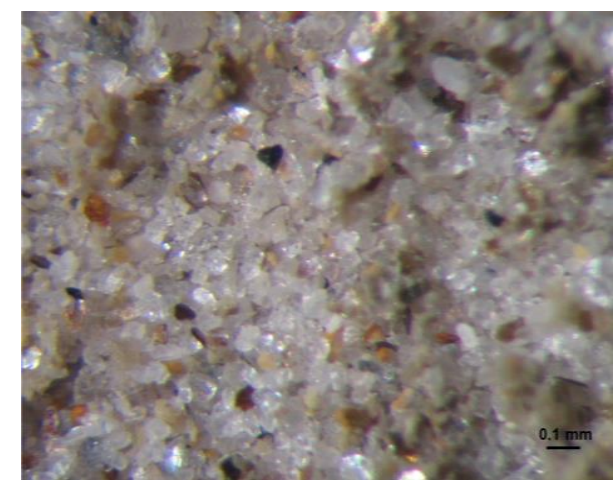

Fig. 10. Fraction $+0.063 \mathrm{~mm}$

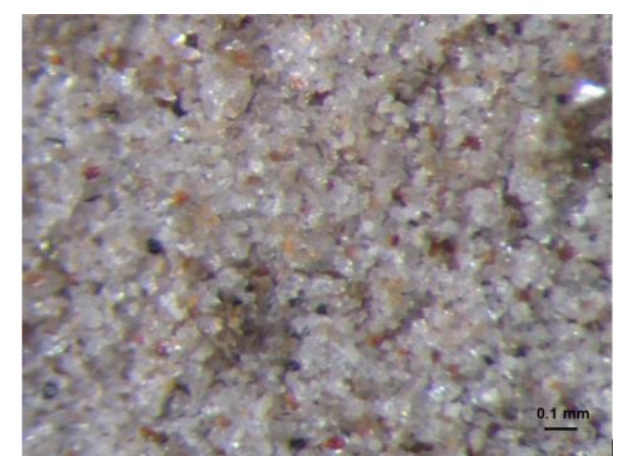

Fig. 11. Fraction $-0.063+0.050 \mathrm{~mm}$

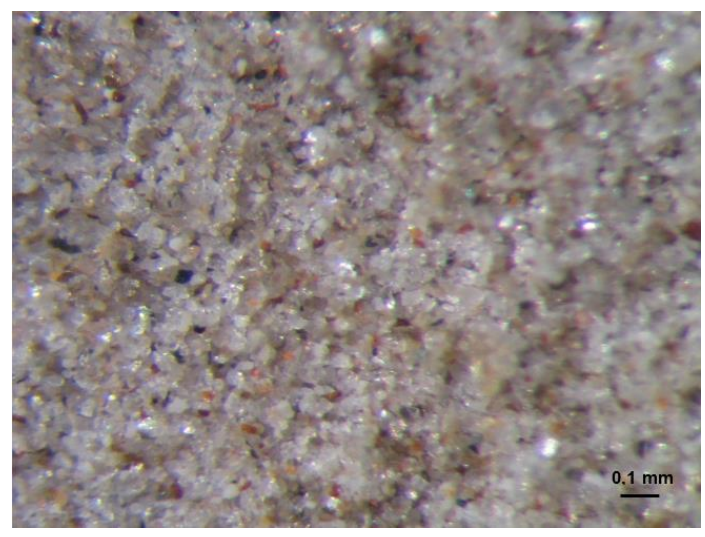

Fig. 12. Fraction $-0.050+0.040 \mathrm{~mm}$

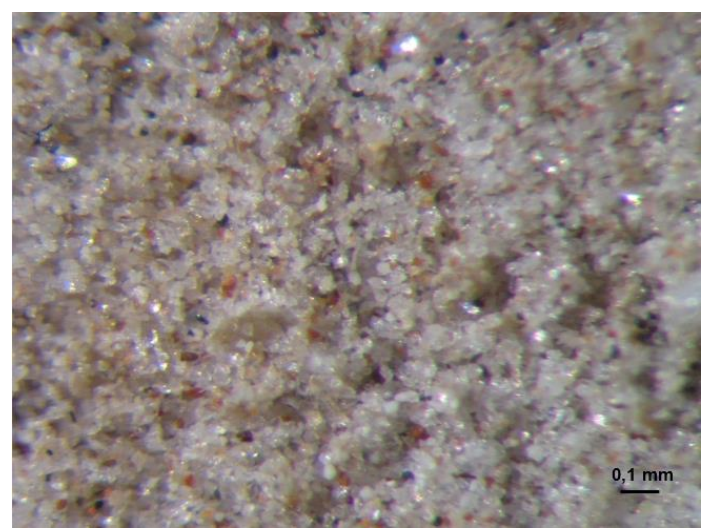

Fig. 13. Fraction $-0.040+0.032 \mathrm{~mm}$

Opposite, the finest fraction $(-0.032 \mathrm{~mm})$ have absolute dominant content of clay particles, with a minor quantitie of admixtures (Figure 14).

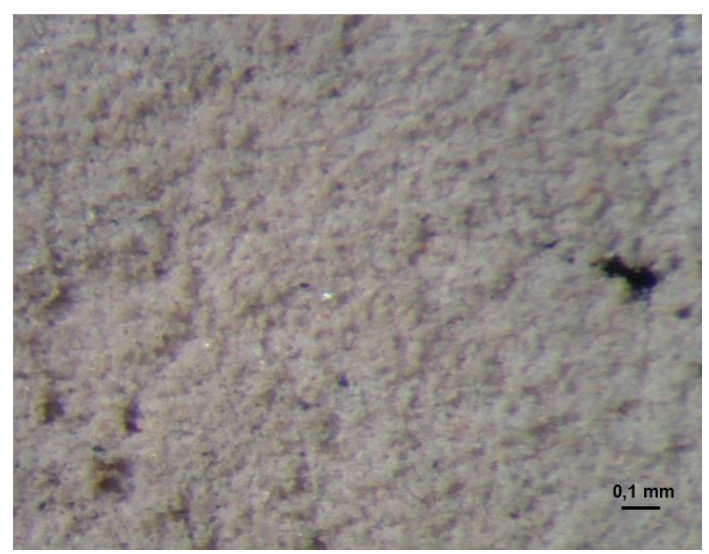

Fig. 14. Fraction $-0.032 \mathrm{~mm}$

Scanning electron microscopy was used to observe the particles morphology. Submicronic constituents of the coarse and fine particles are presented on Figure 15. 


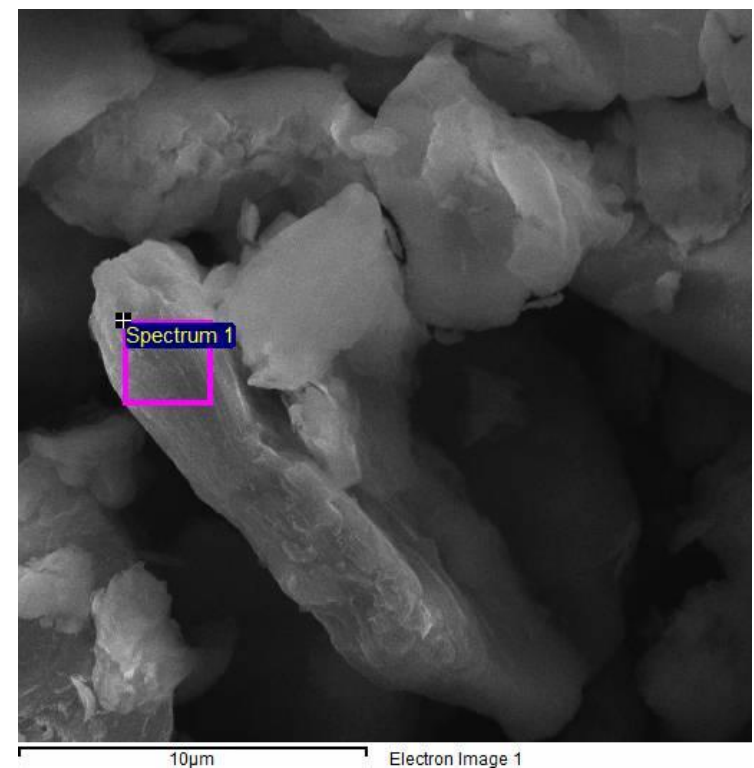

$\stackrel{10 \mu \mathrm{m}}{\longrightarrow}$ Electron Image 1

\begin{tabular}{ccc}
\hline Element & Weight $\%$ & Atomic $\%$ \\
\hline $\mathrm{O}$ & 60.53 & 72.72 \\
$\mathrm{Mg}$ & 1.98 & 1.57 \\
$\mathrm{Al}$ & 13.40 & 9.54 \\
$\mathrm{Si}$ & 22.44 & 15.36 \\
$\mathrm{~K}$ & 1.65 & 0.81 \\
\hline Total & 100.00 & 100.00 \\
\hline \hline
\end{tabular}

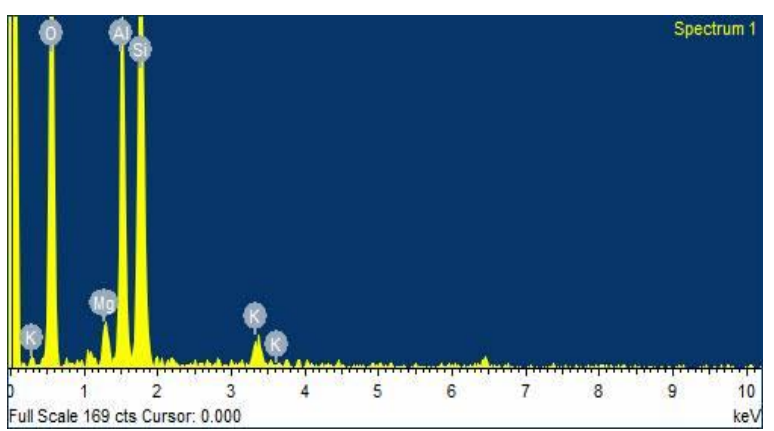

(a)

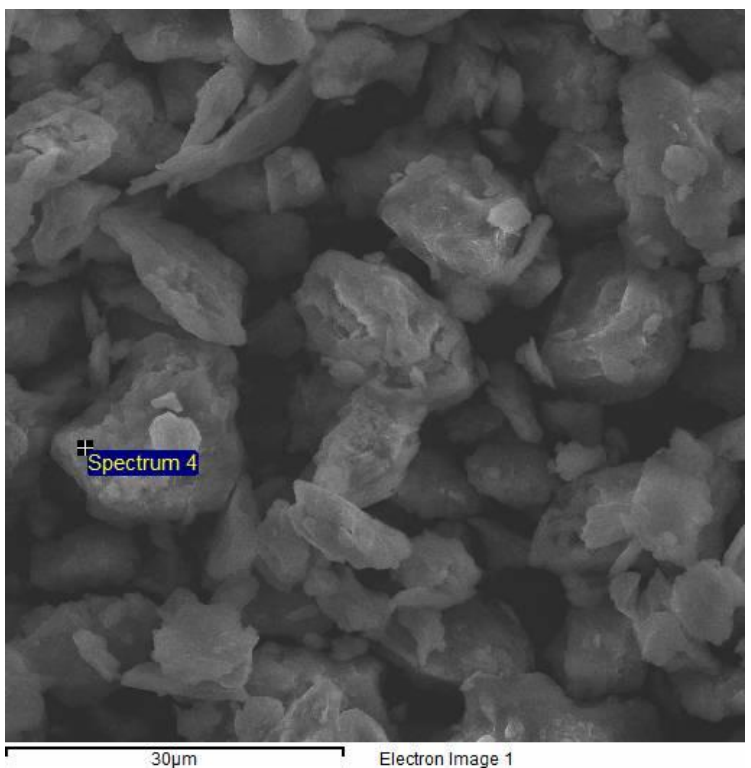

\begin{tabular}{ccc}
\hline \hline Element & Weight $\%$ & Atomic $\%$ \\
\hline $\mathrm{O}$ & 49.02 & 62.61 \\
$\mathrm{Al}$ & 10.05 & 7.61 \\
$\mathrm{Si}$ & 40.93 & 29.78 \\
Total & 100.00 & 100.00 \\
\hline \hline
\end{tabular}

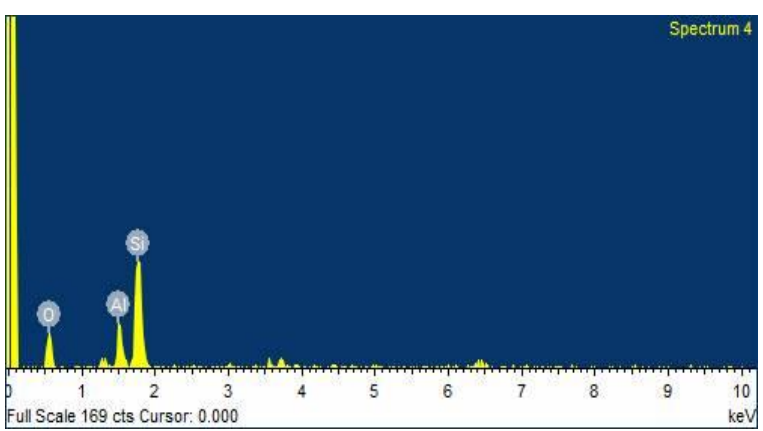

(b)

Fig. 15. SEM-EDS of particle,

(a) fine and (b) coarse

Chemical composition of the various particle size fractions from wet sieve analysis was defined by silicate chemical analysis (Table 3 ). According to the microscopic examinations and XRD there are in significant variations in the coarse fractions from the wet sieve analysis, therefore it is defined average chemical composition of the composite sample from fractions $-0.063+0.050 \mathrm{~mm},-0.050+0.040$ $\mathrm{mm}$ and $-0.040+0.032 \mathrm{~mm}$. As a consequence of the concentration of the admixtures, the content of $\mathrm{SiO}_{2}$ is higher in the coarse fractions $(64.43 \%$ and $56.50 \%$ ), compared to the fine fraction, which has a higher content of $\mathrm{Al}_{2} \mathrm{O}_{3}(16.41 \%)$ due to dominant mass of clay.
Ta b le 3

Chemical composition of various fractions from wet sieve analysis (mass \%)

\begin{tabular}{cccc}
\hline \hline & $(+0,063 \mathrm{~mm})$ & $(-0,063+0.032 \mathrm{~mm})$ & $(-0.032 \mathrm{~mm})$ \\
\hline $\mathrm{SiO}_{2}$ & 64.43 & 56.50 & 51.37 \\
$\mathrm{Al}_{2} \mathrm{O}_{3}$ & 9.21 & 12.20 & 16.41 \\
$\mathrm{Fe}_{2} \mathrm{O}_{3}$ & 5.30 & 5.43 & 5.76 \\
$\mathrm{CaO}$ & 9.21 & 8.12 & 7.70 \\
$\mathrm{MgO}$ & 0.29 & 0.73 & 0.65 \\
$\mathrm{~K} 2 \mathrm{O}$ & 0.90 & 0.58 & 0.66 \\
$\mathrm{Na}_{2} \mathrm{O}$ & 2.19 & 1.66 & 0.50 \\
$\mathrm{SO}_{3}$ & 0.52 & 0.54 & 0.48 \\
$1 . w$ & 7.28 & 13.88 & 15.74 \\
\hline$\Sigma$ & 99.33 & 99.64 & 99.27 \\
\hline \hline
\end{tabular}


DTA/TGA curves of the coarsest $(+0.063 \mathrm{~mm})$ and the finest $(-0.032 \mathrm{~mm})$ fractions from wet sieve analysis are presented on Figures 16 and 17. TGA curve of the finest fraction has a higher loss of mass, as a consequence of structural water decomposition of bentonite.

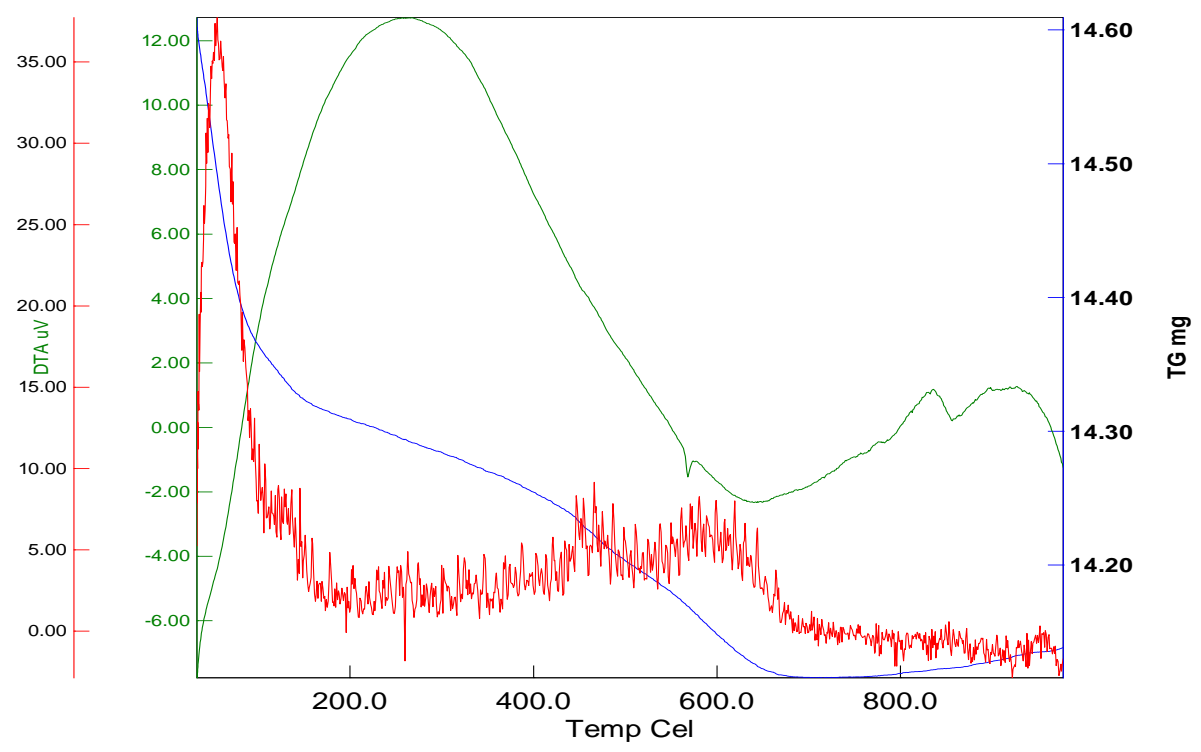

Fig. 16. DTA/TGA of the coarsest fraction $(+0.063 \mathrm{~mm})$ from wet sieve analysis

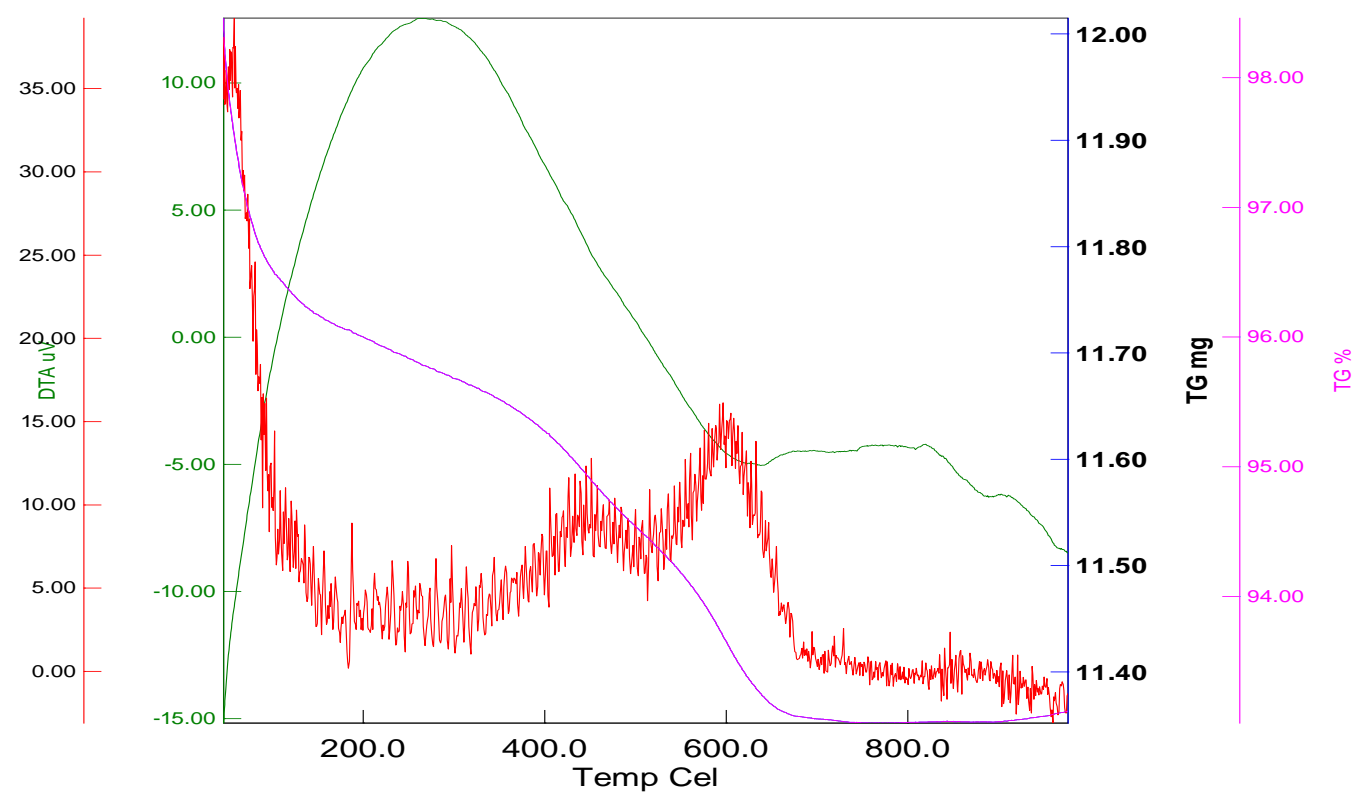

Fig. 17. DTA/TGA of the finest fraction $(-0.032 \mathrm{~mm})$ from wet sieve analysis

Elutriation was applied as a secondary method for separation of the existing admixtures from bentonite clay. Elutriation is a method for separation of particles based on their size, shape and density, using a gas or liquid flowing in the opposite direction from the sedimentation of the particles. This method is mainly used for separation of smaller particles.
Separation of the particles in the elutriation is based on the settling velocity of the particles. If settling velocity of the particle is higher than velocity of water which flow in opposite direction, then the particle will be settled and separate into a coarse fraction (Figure 18). Opposite, if settling velocity of the particle is lower than velocity of water which flow in opposite direction, then the particle will be 
removed with water in over flow and will be separate into a fine fraction.

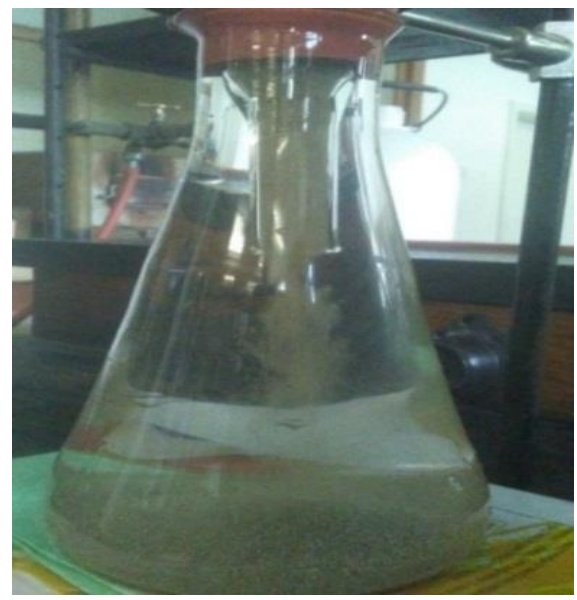

Fig. 18. Sedimentation of coarse particles

The prepared suspension of bentonite clay was classified by Elutriation 1 on coarse fraction settled in an Erlenmeyer flask, and fine fraction removed with water in overflow into a tank. Consecutively, the overflow from Elutriation 1 was classified by Elutriation 2 also on coarse and fine fraction (overflow). Therefore bentonite clay from the prepared suspension was classified by elutriation on three fractions: Elutriation 1 coarse fraction (Coarse fraction), Elutriation 2 coarse fraction (Medium fraction) and Elutriation 2 fine fraction (Fine fraction). The mass contents of classified fractions by Elutriation are presented in Table 4 .

\section{Table 4}

Mass contents of separated fractions by elutriation

\begin{tabular}{lc}
\hline \hline Fraction & Mass content $(\%)$ \\
\hline Coarse fraction & 2.57 \\
Medium fraction & 12.64 \\
Fine fraction & 84.79 \\
\hline$\Sigma$ & 100.00 \\
\hline \hline
\end{tabular}

Microscopic examinations (Figures 19-21) indicate that elutriation as a method has a less effective separation than the wet sieve analysis. Appropriate separation of the bentonite clay provides coarse and fine fractions. Opposite, medium fraction from elutriation (which is not insignificant with
12.64 mass \%) is heterogeneous and contains particles of admixtures as well as clay aggregates.

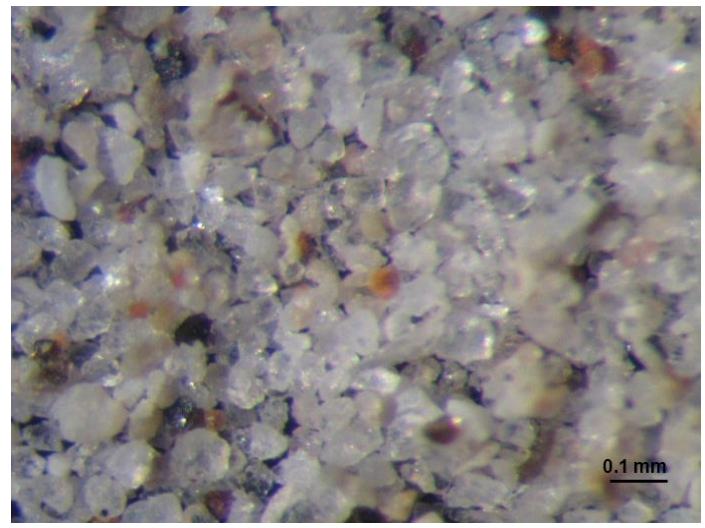

Fig. 19. Coarse fraction of elutriation

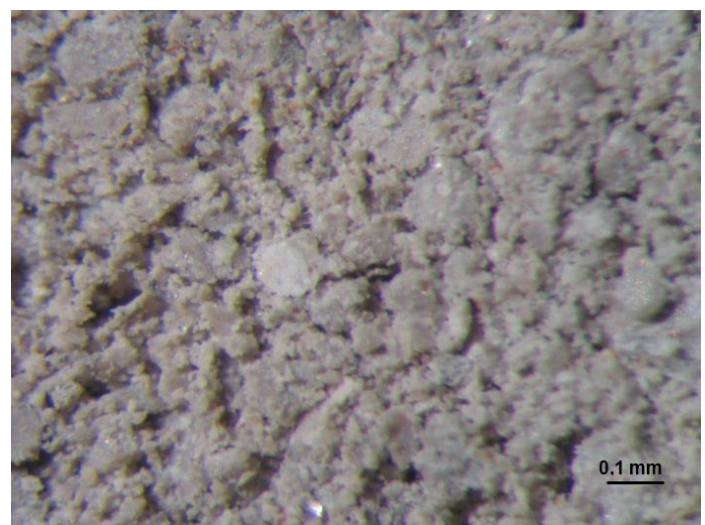

Fig. 20. Medium fraction of elutriation

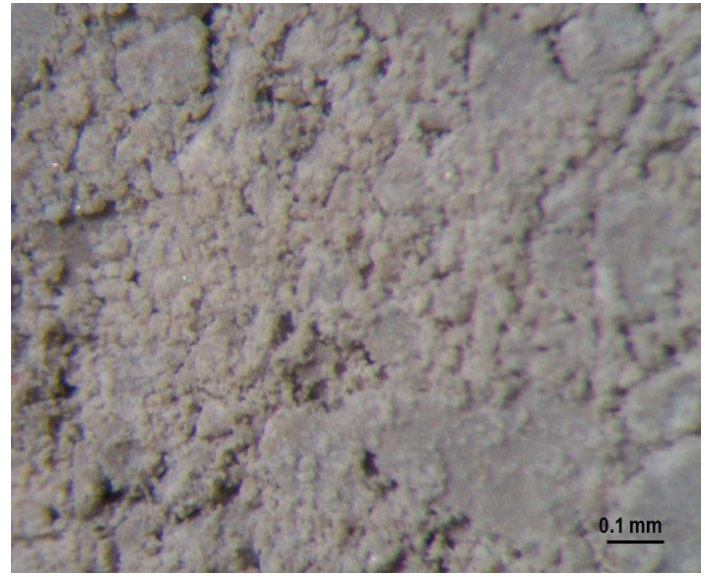

Fig. 21. Fine fraction of elutriation

XRD of various fractions from elutriation (Figure 22) correlate with the microscopic examinations.

The results of silicate chemical analysis of various fractions from elutriation are presented in Table 5 . 


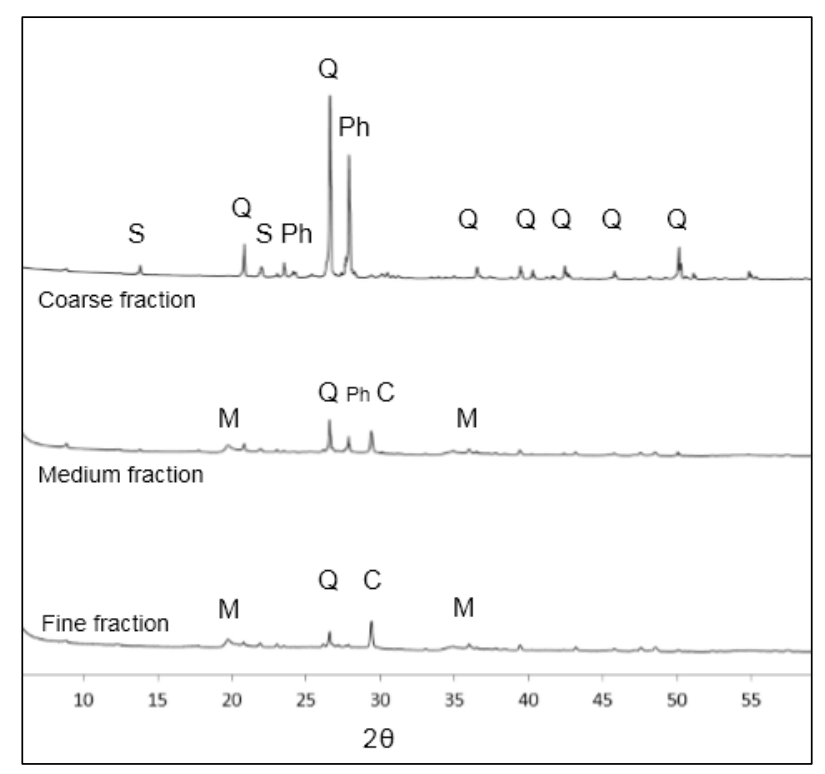

Fig. 22. XRD of various fractions from elutriation ( $\mathrm{Q}$ - quartz, $\mathrm{S}$ - sodalite, $\mathrm{Ph}$ - phlogopite, $\mathrm{C}$ - calcite, $\mathrm{M}$ - montmorillonite)

Table 5

Chemical composition of various fractions from elutriation (mass \%)

\begin{tabular}{lccc}
\hline \hline & $\begin{array}{c}\text { Coarse } \\
\text { fraction }\end{array}$ & $\begin{array}{c}\text { Medium } \\
\text { fraction }\end{array}$ & $\begin{array}{c}\text { Fine } \\
\text { fraction }\end{array}$ \\
\hline $\mathrm{SiO}_{2}$ & 65.25 & 56.83 & 52.69 \\
$\mathrm{Al}_{2} \mathrm{O}_{3}$ & 9.03 & 12.12 & 15.55 \\
$\mathrm{Fe}_{2} \mathrm{O}_{3}$ & 4.64 & 5.07 & 5.57 \\
$\mathrm{CaO}$ & 9.32 & 8.28 & 7.85 \\
$\mathrm{MgO}$ & 0.29 & 0.73 & 0.62 \\
$\mathrm{~K} 2 \mathrm{O}$ & 0.90 & 0.58 & 0.70 \\
$\mathrm{Na}_{2} \mathrm{O}$ & 2.51 & 1.85 & 0.58 \\
$\mathrm{SO}$ & 0.53 & 0.52 & 0.49 \\
$1 . \mathrm{w}$ & 7.36 & 13.67 & 15.27 \\
\hline$\Sigma$ & 99.83 & 99.65 & 99.32 \\
\hline \hline
\end{tabular}

The settling velocity of particles $(v)$ is defined according to Stokes law:

$$
v=\frac{2 \cdot r^{2} \cdot\left(\rho_{p}-\rho_{f}\right) \cdot g}{9 \cdot \mu}(\mathrm{cm} / \mathrm{s})
$$

where:
$v$ is settling velocity $(\mathrm{cm} / \mathrm{s})$,
$r$ is radius of the particle $(\mathrm{cm})$,
$\rho_{p}$ is density of the particle $\left(\mathrm{g} / \mathrm{cm}^{3}\right)$,
$\rho_{f}$ is density of the fluid $\left(\mathrm{g} / \mathrm{cm}^{3}\right)$,

$g$ is acceleration of gravity $\left(\mathrm{cm} / \mathrm{s}^{2}\right)$ and $\mu$ is viscosity of the fluid $(\mathrm{g} / \mathrm{cm} \cdot \mathrm{s})$.

In Table 6 are presented the calculated settling velocity $(\mathrm{mm} / \mathrm{s})$ for particles with various dimensions of the existing minerals in the bentonite clay.

According to the defined flow of water (Elutriation 1 with $Q_{1}=180 \mathrm{~cm}^{3} / \mathrm{min}$, and Elutriation 2 with $Q_{2}=120 \mathrm{~cm}^{3} / \mathrm{min}$.), and taking into consideration diameter $d=42 \mathrm{~mm}$, the velocities of water $(V)$ in the tube were calculated:

$$
\begin{aligned}
V_{1} & =2.166 \mathrm{~mm} / \mathrm{s} \\
V_{2} & =1.444 \mathrm{~mm} / \mathrm{s} .
\end{aligned}
$$

Therefore by Elutriation 1, where the velocity of water in the tube $V_{1}=2.166 \mathrm{~mm} / \mathrm{s}$, particles of the existing admixtures (quartz, phlogopite, sodalite, calcite) with dimensions larger than $50 \mu \mathrm{m}$ were separated into the coarse fraction (Figure 19.). Then by Elutriation 2, where the velocity of water $V_{2}=$ $1.444 \mathrm{~mm} / \mathrm{s}$, the particles of the existing admixtures with dimensions of $40-50 \mu \mathrm{m}$, as well as the clay aggregates were separated into the medium fraction (Figure 20). Consecutively into a fine fraction from elutriation, removed in overflow, particles of clay with dimension smaller than $40 \mu \mathrm{m}$ were separated (Figure 21).

The settling velocity primarily depend of specific mass (density) and size (dimension) of the particle. Particles of various minerals of a wide range of dimensions can be separated into specific fractions (as the medium fraction of elutriation, Figure 20), reducing the separation efficiency of elutriation. Aggregation of the clay particles (Figure 23) resulting with certain deviations in the settling velocity, also has a negative impact on the separation efficiency of the elutriation.

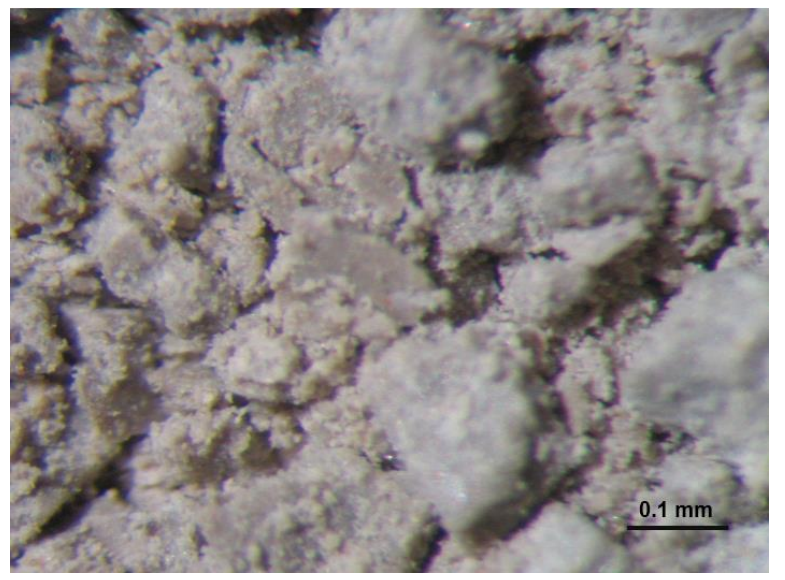

Fig. 23. Aggregated clay particles 
Table 6

Settling velocity $(\mathrm{mm} / \mathrm{s})$ of particles for various minerals

\begin{tabular}{|c|c|c|c|c|c|}
\hline \multirow{2}{*}{$\begin{array}{l}\text { Particle size } \\
\qquad(\mu \mathrm{m})\end{array}$} & \multicolumn{5}{|c|}{ Settling velocity $(\mathrm{mm} / \mathrm{s})$} \\
\hline & Montmorillonite & Quartz & Phlogopite & Calcite & Sodalite \\
\hline 2 & 0.003 & 0.004 & 0.004 & 0.004 & 0.003 \\
\hline 4 & 0.012 & 0.014 & 0.016 & 0.015 & 0.011 \\
\hline 6 & 0.026 & 0.032 & 0.035 & 0.033 & 0.026 \\
\hline 8 & 0.047 & 0.058 & 0.063 & 0.059 & 0.045 \\
\hline 10 & 0.074 & 0.090 & 0.098 & 0.093 & 0.071 \\
\hline 12 & 0.106 & 0.129 & 0.141 & 0.133 & 0.102 \\
\hline 14 & 0.144 & 0.176 & 0.192 & 0.182 & 0.139 \\
\hline 16 & 0.188 & 0.230 & 0.251 & 0.237 & 0.181 \\
\hline 18 & 0.238 & 0.291 & 0.318 & 0.300 & 0.230 \\
\hline 20 & 0.294 & 0.360 & 0.392 & 0.371 & 0.283 \\
\hline 22 & 0.356 & 0.435 & 0.475 & 0.448 & 0.343 \\
\hline 24 & 0.424 & 0.518 & 0.565 & 0.534 & 0.408 \\
\hline 26 & 0.497 & 0.608 & 0.663 & 0.626 & 0.479 \\
\hline 28 & 0.577 & 0.705 & 0.769 & 0.726 & 0.555 \\
\hline 30 & 0.662 & 0.809 & 0.883 & 0.834 & 0.638 \\
\hline 32 & 0.753 & 0.921 & 1.005 & 0.949 & 0.726 \\
\hline 34 & 0.851 & 1.040 & 1.134 & 1.071 & 0.819 \\
\hline 36 & 0.954 & 1.165 & 1.271 & 1.201 & 0.918 \\
\hline 38 & 1.062 & 1.299 & 1.417 & 1.338 & 1.023 \\
\hline 40 & 1.177 & 1.439 & 1.570 & 1.482 & 1.134 \\
\hline 42 & 1.298 & 1.586 & 1.730 & 1.634 & 1.250 \\
\hline 44 & 1.424 & 1.741 & 1.899 & 1.794 & 1.372 \\
\hline 46 & 1.557 & 1.903 & 2.076 & 1.960 & 1.499 \\
\hline 48 & 1.695 & 2.072 & 2.260 & 2.135 & 1.632 \\
\hline 50 & 1.839 & 2.248 & 2.453 & 2.316 & 1.771 \\
\hline 52 & 1.989 & 2.432 & 2.653 & 2.505 & 1.916 \\
\hline 54 & 2.145 & 2.622 & 2.861 & 2.702 & 2.066 \\
\hline 56 & 2.307 & 2.820 & 3.076 & 2.906 & 2.222 \\
\hline 58 & 2.475 & 3.025 & 3.300 & 3.117 & 2.383 \\
\hline 60 & 2.649 & 3.237 & 3.532 & 3.335 & 2.551 \\
\hline 62 & 2.828 & 3.457 & 3.771 & 3.561 & 2.723 \\
\hline 64 & 3.014 & 3.683 & 4.018 & 3.795 & 2.902 \\
\hline 66 & 3.205 & 3.917 & 4.273 & 4.036 & 3.086 \\
\hline 68 & 3.402 & 4.158 & 4.536 & 4.284 & 3.276 \\
\hline 70 & 3.605 & 4.406 & 4.807 & 4.540 & 3.472 \\
\hline 72 & 3.814 & 4.662 & 5.086 & 4.803 & 3.673 \\
\hline 74 & 4.029 & 4.924 & 5.372 & 5.074 & 3.880 \\
\hline 76 & 4.250 & 5.194 & 5.666 & 5.351 & 4.092 \\
\hline 78 & 4.476 & 5.471 & 5.968 & 5.637 & 4.311 \\
\hline 80 & 4.709 & 5.755 & 6.278 & 5.930 & 4.534 \\
\hline
\end{tabular}




\section{CONCLUSION}

One of the commercial products from Bentomak, bentonite clay $(-0.063 \mathrm{~mm})$ contains montmorillonite as basic mass, and quartz, calcite, sodalite, phlogopite as admixtures. Wet sieve analysis and elutriation were applied as methods for separation of admixtures.

A higher degree of separation provides a wet sieve analysis. Mineralogical-petrographic examinations confirm that the existing admixtures are separated into coarse fractions. The coarse fractions dominantly contain admixtures and minor quantities of clay aggregates. Aditionally the clay was concentrated in the finest fraction $(-0.032 \mathrm{~mm})$. Therefore the finest fraction separated from admixtures has wide a range of high profitable practical applications.

Elutriation as a method has a lower degree of separation. The medium fraction from elutriation has a heterogeneous composition of admixtures and clay. The main reason for incompleted separation in the elutriaton process is the aggregation and agglomeration of the fine clay particles on the surface of the coarse particles of the admixtures. The formed aggregates and agglomerates have acertain variability in the velocity of sedimentation, which resulted with sedimentation in various fractions.

\section{REFERENCES}

Alves, J. L., Zanini, E. A., De Souza, M. E., Nascimento, M. L. F.: Study of selection and purification of Brazilian bentonite clay by elutriation: a XRF, SEM and Rietveld analysis, Cerâmica, 62 (361), 1-8 (2016).

Atkovska, K., Bliznakovska, B., Ruseska, G., Bogoevski, S., Boškovski B., Grozdanov, A.: Adsorption of Fe(II) and $\mathrm{Zn}$ (II) ions from landfill leachate by natural bentonite, Journal of Chemical Technology and Metallurgy, 51 (2), 215-222 (2016).

Barakan, S., Aghazadeh, V.: Separation and characterisation of montmorillonite from a low-grade natural bentonite: using a non-destructive method, Micro \& Nano Letters, 14 (6), 688-693 (2019).

Bogoevski, S., Jančev, S., Boškovski, B.: Characterization of Diatomaceous Earth from Slaviško Pole locality in the Republic of Macedonia, Geologica Macedonica, 28 (1), 39-43 (2014).

Bogoevski, S., Boškovski, B., Ruseska, G., Atkovska, K.: Concentration of carbonate admixtures from opalized tuff into one separate fraction, Geologica Macedonica, 30 (1), 89 95 (2016).

Boševska, V.: Structure and physico-chemical properties of thermally treated natural and soda active bentonites, $\mathrm{PhD}$ thesis, Institute of Chemistry, Faculty of Natural Sciences and Mathematics, "Ss Cyril and Methodius" University in Skopje, 1980.

Brezovska, S.: Physic-chemical bases of the production of adsorbents from bentonites and the possibilities of its application as stabilizers in the processes of polymerization, $\mathrm{PhD}$ thesis, Faculty of Technology and Metallurgy, "Ss Cyril and Methodius" University in Skopje, 1996.

Brezovska, S., Marina, B., Panova, B., Burevski, D., Boševska, V., Stojanovska, L.: The adsorption characteristics and porous structure of bentonite adsorbents as determined from the adsorption isotherms of benzene vapor, Journal of the Serbian Chemical Society, 69 (2), 145-151 (2004).

Brezovska, S., Marina, B., Burevski, D., Angjuševa, B., Boševska, V., Stojanovska, L.: Adsorption properties and porous structure of sulfuric acidtreated bentonites determined by the adsorption isotherms ofbenzene vapor, Journal of the Serbian Chemical Society, 70 (1), 33-40 (2005).

Guerra, D. J. L., Mello, I., Resende, R., Silva, R.: Aplication as absorbents of natural and functionalized Brasilian bentonite in $\mathrm{Pb}^{2+}$ adsorption: Equilibrium, kinetic, $\mathrm{pH}$, and thermodynamic effects, Water Resources and Industry, 4, 3250 (2013).

Khan, M. R., Hegde, R. A., Shabiimam, M. A.: Adsorption of Lead by Bentonite Clay, International Journal of Scientific Research and Management, 5 (7), 5800-5804 (2017).

Knežević, D.: Priprema mineralnih surovina, Rudarsko-geološki fakultet, Beograd, 2001.

Memedi, H., Atkovska, K., Lisichkov, K., Marinkovski, M., Kuvendziev, S., Bozinovski, Z., Reka, A. A.: Separation of $\mathrm{Cr}$ (VI) from aqueous solutions by natural bentonite: Equilibrium study, Quality Of Life, 8 (1-2), 41-47 (2017).

Moosavi, M.: Bentonite Clay as a Natural Remedy: A Brief Review, Iranian Journal of Public Health, 46 (9), 1176-1183 (2017).

Nikolovski, M., Podgotovka na mineralni surovini, Rudarskogeološki fakultet, Univerzitet „Sv. Kiril i Metodij“, Skopje, 1995.

Park, J. H., Shin, H. J., Kim, M. H., Kim, J. S., Kang, N., Lee, J. Y., Kim, K. T., Lee, J. I., Kim D. D.: Application of montmorillonite in bentonite as a pharmaceutical excipient in drug delivery systems, Journal of Pharmaceutical Investigation, 46, 363-375 (2016).

Pavlovski, B., Jančev S., Petreski, Lj., Reka, A., Bogoevski, S., Boškovski B.: Trepel - a peculiar sedimentary rock of biogenetic origin from the Suvodol Village, Bitola, R. Macedonia, Geologica Macedonica, 25 (1), 67-72 (2011).

Reka, A., Anovski, T., Bogoevski, S., Pavlovski, B., Boškovski, B., Physical-chemical and mineralogical-petrographic examinations of diatomite from deposit near village Rožden, R. Macedonia, GeologicaMacedonica, 28 (2), 121-126, (2014). 
Sarbatly, R., Yee, C. P., Fong, T.S., Krishnaiah, D., Particle Size Distribution and Purification of Red Clay for Industrial Use, Journal of Applied Sciences, 9 (12), 2344-2347, (2009).

Spasovski, O., Mirčovski, V., Mitrovski, S.: Geological characteristics of the Ginovci bentonite clay deposits in the vicinity of Kriva Palanka, Republic of Macedonia, The third conference on mineral resources, their exploitation, ceramic and brick production, pp 63-67 (2003).

Stojanović, M., Naođališta na nemetalni surovini vo Makedonija, Skopje, 2005.

Zafirovski, S., Pavlovski, B., Sapunov, P.: Priračnik za nemetalni surovini I proizvodi so metodi za nivno ispituvanje, Univerzitet “Sv. Kiril I Metodij”, Skopje, 1974.

\title{
Р е 3 и м е
}

\section{КАРАКТЕРИЗАЦИЈА НА ГРАНУЛОМЕТРИСКИТЕ ФРАКЦИИ ОД БЕНТОНИТСКАТА ГЛИНА ОД ГИНОВЦИ, РЕПУБЛИКА СЕВЕРНА МАКЕДОНИЈА}

\author{
Бошко Бошковски, Слободан Богоевски

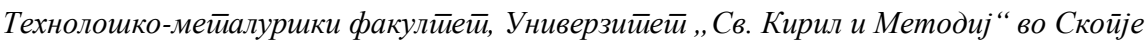 \\ Руѓер Бошковиќ 16. 1000 Скойје, Рейублика Северна Македонија \\ bboskovski@tmf.ukim.edu.mk
}

\begin{abstract}
Клучни зборови: бентонитска глина; примеси; гранулометриски фракции; мокра гранулометриска анализа; елутрација.
\end{abstract}

\begin{abstract}
Испитуваната бентонитска глина како основна маса содржи монтморилонит. Како примеси се јавуваат кварц, илити и други минерали. Примесите се нехомогено дистрибуирани во различните гранулометриски фракции. Целта на ова истражување е концентрација и сепарација на примесите од бентонитската глина $(-0.063 \mathrm{~mm})$, комерцијален производ на Бентомак. Како методи за сепарација беа при-
\end{abstract}

менети мокра гранулометриска анализа и елутријација. За да се дефинира ефикасноста на методите, беа направени комплексни испитувања за карактеризација на фракциите. Симултаниот преглед на резултатите од рентденската, микроскопската и хемиската анализа покажа дека во најфината фракција $(-0.032 \mathrm{~mm})$ концентрацијата на примесите е помала за 80\% во однос на другите фракции. 
